\title{
12. Community-building and Security: Case Studies
}

\author{
SINCLAIR DINNEN, JOHN CARTWRIGHT, \\ MADELEINE JENNEKER, CLIFFORD SHEARING, \\ ISAAC WAI, PAUL MAIA
}

\section{Governance of Security}

\section{Sinclair Dinnen}

Aral, Burris and Shearing argue that a shared sense of security from physical violence and interference with property contributes significantly to better community health (2002, 632; see also Burris 2006). Conversely, the absence of security can have devastating consequences for the health of individuals, communities and, indeed, nations. As well as its direct impact on the health of victims, violence has indirect effects that erode the quality of life and the ability to improve social and economic conditions (Emmett and Butchart 2000). These include, for example, the impediment that it presents to investment for economic development, its impact on tourism, and the way it can fuel the emigration of skilled citizens to more secure environments. Violence and conflict can corrode family and community ties, and disrupt the provision of basic health, education and other social services. High levels of sexual violence at home, or on the streets, undermine the freedoms and rights of women and children. In doing so, they deprive society and the economy of the full participation of a large proportion of the population. The manner in which any given society seeks to control crime, violence and other disputes - the governance of security - can thus be seen as a priority for public health research and intervention. Other chapters in this volume have shown how violence against women directly fuels HIV, which, in turn, contributes to conditions for further violence and insecurity.

In modern societies, the state has long been attributed the central role in the provision of security, as echoed in Max Weber's famous dictum about the state 
exercising a monopoly over the legitimate use of violence (Weber 1972). As far as internal security within designated territorial borders is concerned, this role has fallen traditionally to the state's law and justice system and the complex of associated agencies and institutions dedicated to the enforcement and administration of state law. These include, most obviously, the police, the courts and the prisons. Those suspected of infringing the law are apprehended by the police and taken out of their communities, prosecuted in the name of the state in the judicial system, and, if found guilty, punished. The interests of those most directly affected by their criminal behaviour are deemed to be satisfied by the imposition of state-administered retribution through the formal judicial and penal process. Civil dispute resolution is similarly removed from those most directly affected and managed by the judicial system and its cadre of professional officers-lawyers, magistrates and judges.

While few would disagree with the premise that states have a fundamental obligation to ensure a secure environment for their citizens, most would acknowledge that the governance of security is not exclusively a state function. State-centred approaches to the governance of security have undergone considerable scrutiny and reform in 'developed' countries as their inherent limitations have become more apparent and as recognition of the potential role of other stakeholders has grown. In many jurisdictions, emphasis is now placed on resolving small disputes through arbitration and other means in order to avoid costly and time-consuming legal proceedings. Recognition of the often harmful and counter-productive effects of imprisonment on offenders, as well as its considerable costs, has resulted in resort to alternatives to imprisonment for minor and juvenile offences, while the needs of 'victims' of crime are recognised in the expansion of restorative justice schemes in many countries.

Other harms, such as those caused to the innocent dependents of imprisoned offenders, appear to be an unavoidable consequence of the way the system works. Despite their universality and institutional complexity, criminal justice systems are, in fact, extremely crude instruments for deterring violence and settling conflict. They routinely exclude 'victims' from any meaningful participation in the resolution of disputes or offences that have affected them personally. In this sense, they steal conflicts away from those most directly involved and affected by them (Christie 1977). Experience of state-administered incarceration appears just as likely to accentuate criminal and anti-social attitudes on the part of individual offenders as 'rehabilitate' or 'correct' them in line with the rhetoric embraced by most modern penal regimes.

The Weberian depiction of the state and its pivotal role in the governance of security is, of course, an ideal and the reality in most societies is very different. In today's era of lean government and extensive out-sourcing, the monopoly over security functions of even the most long-established states has been 
diminished as a result of rising levels of private sector involvement in areas previously monopolised by the state. This is illustrated in, among other things, the massive growth of private policing and security (Shearing and Stenning 1987), including the controversial expansion of private military security (Singer 2001), as well as the increase in private prisons (Parenti 1999). In other less wellestablished states, centralised authorities have struggled hard to assert their writ successfully across the length and breadth of their designated territories. Law enforcement agencies, and other law and justice institutions, often have limited institutional capabilities and geographic reach in resource poor countries. In some cases, criminal justice agencies and processes designed to deter crime and disorder have themselves become a major source of harm and insecurity. Problems of corruption and serious abuse of human rights on the part of such agencies reflect, in part, a lack of adequate support and effective regulation by government. For example, prisons with insufficient funds and staff find it hard to maintain humane regimes and can become major incubators for violence and the transmission of deadly infections like HIV.

In countries, like Papua New Guinea, with predominantly rural populations, ordinary citizens may face significant difficulties in accessing justice, particularly when the state's justice facilities are concentrated overwhelmingly in urban centres. The prohibitive fees of lawyers and other associated costs provide further inhibitors. In such circumstances, the quality of 'justice' available may be determined more by an individual's wealth and place of abode than by idealised notions of equality of law. Moreover, where structural factors contribute to high levels of poverty, social exclusion and inequality, the operation of the criminal justice system can appear heavily weighted against those confronting the daily struggle to sustain themselves and their families. The targeting of disadvantaged communities for reactive policing and other repressive 'law and order' measures, as well as their over-representation in the prison population, can reinforce cycles of poverty and alienation rather than alleviate them. Criminal justice is designed to incapacitate and punish those who have or are likely to harm others. It affords little opportunity to acknowledge - let alone address - deeper structural factors that contribute to conflict, violence and anti-social activities in particular societies. The state system is oriented primarily towards control rather than prevention.

Where large numbers of people remain beyond the reach of formal justice processes or are otherwise disinclined to use them, informal responses to disputes and infractions of community norms are likely to prevail. In countries like Papua New Guinea, these include resort to older practices of dispute resolution and social control, associated with long traditions of self-regulation, as these have adapted to social and economic change. Reliance on local solutions is, in many cases, driven by the absence or weakness of state controls. It may 
also reflect a preference for familiar and socially attuned resolutions to local problems rather than reliance on external and impersonalised models. While some of these informal responses operate without any involvement of state or other external bodies, most others work with the explicit or tacit approval of relevant bits of state, NGOs, churches, or private sector bodies.

Informal approaches can work well in relatively cohesive communities. However, in other cases they can infringe seriously upon the rights of vulnerable groups such as women and children, thereby compounding their existing disadvantage. Likewise, in the absence of linkages to the formal regulatory system, informal responses can become the norm for dealing with all manner of disputes, including serious criminal matters, such as rape and murder, which legally should only be dealt with by the state through its higher courts. Informal approaches are also susceptible to capture by powerful local interests, such as older men whose actions are legitimated in the name of 'traditional' or 'customary' authority or, in seriously fractured and militarised environments, by younger men in possession of guns or other means of intimidation. In some parts of the world, including South Africa, informal self-policing has sometimes deteriorated into violent vigilantism.

Without effective regulation and accountability, informal approaches - as with their formal counterparts - can become quickly 'corrupted' and 'brutalised' and, thereby, a source of further injustice and insecurity. In addition, where informal approaches include the payment of monetary compensation, as in many parts of Melanesia, profit can become the predominant motive, thereby contributing to the further distortion and corruption of such practices (Fraenkel 2004). This is evident where relatives of a victim of gender violence or sexual abuse project themselves as the principal victims and seek to profit from the offence. In such circumstances, the actual victim is often left without any effective remedy.

In 2000, the PNG government endorsed a National Law and Justice Policy (GoPNG 2000) that recognised the need to develop partnerships between communitybased organisations and state agencies aimed at enhancing safety and security at local levels. These have resulted in a flurry of activities including support of local dispute resolution mechanisms such as peace committees, human rights and law awareness initiatives, cooperation between police and community-based peace and safety processes, and increased support to the Village Court system operating at local levels throughout the country (Goddard 2009). Informing the policy was the long and frustrating experience of trying to respond to the growth of violence and conflict that has marked the past three decades in many parts of the country. While the need to improve the effectiveness of the state's formal deterrence system provides a major pillar of the new policy, it is accepted that the task of enhancing community safety also requires the active participation of community and civil society actors. Reflecting the thinking of 
the seminal Clifford Report on Law and Order (Clifford et al. 1984), the policy acknowledges that sustainable peace cannot be imposed on communities by state agencies acting alone. What is also needed is the building of local capacity that will enable community organisations to take more responsibility for solving their own problems.

Building the governance capacity of local organisations (or 'community-building' as the policy puts it) is thus seen as a key strategy for violence reduction and conflict prevention in PNG's diverse communities, as well as for enhancing their overall health and wellbeing. This would include a focus on addressing some of the underlying factors that contribute to violence and conflict in particular areas, such as lack of sustainable livelihoods or recreational facilities for local youth, as well as on strengthening community-based conflict resolution mechanisms. There is an implicit acknowledgement that problems of crime and violence reflect the weakness of both formal (state) and informal (non-state) controls, as well as the absence of pathways out of poverty, marginalisation and criminality.

Developing partnerships between state agencies, such as the police, and local organisations involved in addressing conflict would, in theory, have other mutually beneficial outcomes. For example, they could serve as vehicles for infusing informal approaches with respect for human rights and awareness of public health issues including HIV, while simultaneously rendering the police and other formal agencies more responsive to local needs and accountable to ordinary citizens. Available evidence suggests that community policing initiatives in different parts of the country, often involving police working with local peace or law and order committees, have achieved some success in enlisting young men at risk of engaging in criminal behavior and working with women's groups around issues of violence and public health (JAG 2004).

The alarming (alarmist?) portrayal of Papua New Guinea as uniformly beset by an expanding epidemic of crime and wanton violence inevitably overlooks the diversity of local experiences and responses. Given the predilection for 'bad news' in the local media and many external representations, it is hardly surprising that the rich array of problem-solving initiatives that are to be found throughout PNG, including in some of the most seriously disadvantaged rural and urban areas, are rarely reported (Hegarty and Thomas 2005; James et al. 2009). These would include the remarkable peace-building efforts of the Kup Women for Peace in a part of Simbu Province that had suffered from many years of violent inter-group conflict (Garap 2004; Hinton et al. 2008). There are also plenty of examples from post-conflict Bougainville where innovative community-based approaches to reconciliation and peace-building have met with considerable success (Howley 2002; Boege 2009). 
Many of these initiatives have taken place far from the view of the urbanbased media, national policy community, international donors, centres of commerce and foreign embassies. Without understating the challenges they face in sustaining themselves over time, it is important to acknowledge the agency and ingenuity of local actors in practical attempts to overcome adverse circumstances, including efforts to transform their own systems of governance in order to address better the problems of violence and conflict (Regan 2005). More significantly, it is important to study these cases in order to learn from their successes and failures and extend this learning to other communities facing similar problems.

The following two case studies examine local responses to problems of human security in disadvantaged urban communities - one in South Africa, the other in Port Moresby. Cartwright et al. outline the rationale and workings of the Zwelethemba model in South Africa, a model of what they call 'local capacity governance'. It offers a mechanism for communities to govern their own security while avoiding the problems associated with both formal and informal approaches to conflict and violence. At its core, the Zwelethemba model is a locally driven attempt to build community cohesion by connecting local and translocal structures. It seeks to mobilise capacity and knowledge within poor multi-ethnic communities in order to enhance the governance of their own security while simultaneously attracting the resources needed to support community-building through, for example, income-generating schemes. Resolving disputes through the agency of local peace committees is thus viewed as a window through which to address deeper social and economic problems, such as lack of local capacity and legitimate economic opportunities.

As noted earlier by Luker and Dinnen (this volume, chapter one), the Zwethelemba model is designed for a particular environment and would not necessarily work everywhere. However, the basic principles underlying the model could, in theory, be adapted and transferred elsewhere, as, indeed, they are in other South African cities and parts of Argentina. The Zwelethemba model clearly articulates certain features of interest to the present volume, including:

- Defining an effective, strategic but nevertheless limited role for the state. As described below, this includes conformity with state law, including the National Constitution; good working relations, with the South African Police Service and Department of Justice, as well as with individual police station commanders and magistrates in the areas where the Peace Committees operate. Many other possibilities exist for developing appropriate forms of state cooperation, including a light regulatory role, such as the use of state facilities or requiring the keeping of records.

- Utilising locally abundant resources: knowledge and time. 
- Delivering a two-tiered 'peace dividend': two-thirds of payments to Peace Committees are divided among committee members, thereby acknowledging and valuing individual local expertise; while the remaining one-third goes into a community development fund to be spent on local projects collectively determined by members of the community.

- Operating on two tiers of prevention: resolving conflicts before they escalate; and potentially preventing some conflicts before they arise, through initiating and funding community projects which address local needs.

- Linking peacemaking and peacebuilding in a way that co-generates a new civics and new forms of community development.

- Enfranchising women and youth: according to the statistics provided, 59 percent of participants were women and 17 percent were youth.

The Zwelethemba model has also benefited from the research and monitoring work undertaken by the University of the Western Cape and the considerable international interest in its innovative approach. This has enabled a process of learning and development, as well as critical linkages and support from a range of external stakeholders including state agencies, like the police, and donor organisations.

While there is no evidence of any direct communication between them, it is striking that the second case study from Saraga settlement in Port Moresby demonstrates important similarities to the South African initiative. As with the Zwelethemba model, the fundamental aim of Saraga's peace committees is to build community cohesion and use conflict mediation to address some of the community's more fundamental challenges. It is also a locally driven approach that seeks to mobilise local knowledge and capacity in addressing local problems and develop supportive relations with external (translocal) bodies on the community's own terms. One of the practical challenges it faces, along with similar self-help initiatives in PNG, is how informal mediation by local groups relates to the mediation services provided by the government-administered Village Courts system. There is the risk that informal mediation services might undermine the authority and role of the more formal Village Courts. Efforts have been made by agencies like the Community Justice Liaison Unit (see below) and NGOs involved in providing mediation training to ensure that informal community-based approaches such as those developed in Saraga operate in a complementary manner with the Village Courts.

Unlike the South African case, Saraga has not been the subject of extensive research or international interest. Indeed, it remains relatively little known beyond the immediate community itself and individual supporters in a number of external agencies, companies, and NGOs. As a result, it remains essentially a one-off initiative that is unique to Saraga and highly dependent on the energy and leadership of a small group of community members and external supporters, 
mainly from the business sector. This makes it vulnerable to changes in key personnel or supporters, as happened when Downer Construction closed down. It also makes the task of developing a sustainable model, whose principles can be applied elsewhere, more difficult. The Zwelethemba model has been more successful in linking the economic incentives for conflict resolution to community development. Likewise, it has been more effective in institutionalising the necessary linkages between local and translocal structures.

Many of the ideas informing the Zwelethemba model correspond with those underlying the AusAID-supported Democratic Governance Strategy in PNG that aims 'to help articulate demands for democratic processes and institutions in PNG, and support the required reforms of the state and civil society to meet that demand' (AusAID 2007). The related initiative Strongim Pipol Strongim Nesen (Empower People: Strengthen the Nation) aims 'to enable civil society, together with the state and others, to better meet the needs and priorities of men, women and children in communities across PNG' (SPSN n.d.) . Its main components comprise:

1. Strengthened practice and promotion of democratic governance by key partners;

2. Communities working together to address identified priorities;

3. Improving local governance in selected geographic areas;

4. Strengthened collaboration of men and women stakeholders for the promotion of democratic governance;

5. Strengthened human capital of men and women for the practice of democratic governance (SPSN n.d.).

The thinking behind these initiatives as described by one of their key advisers (Goudsmit 2008) includes the need to use the limited local capacities of the state to greatest effect; to better mobilise existing local resources; to link peacemaking and peacebuilding with real development; and the need to develop a new 'civics', drawing upon a hybrid of local and state forms. These ideas appear to resonate with recent community policing and locally initiated peace strategies in different parts of PNG, some of which have also explicitly involved HIV education efforts, ${ }^{1}$ gender violence initiatives, as well as the enlisting of women ${ }^{2}$ and male youth. ${ }^{3}$ Instead of trying to impose a top-down

\footnotetext{
1 A story in the PNG Post-Courier (23 August 2006) reports the efforts of Detective Sargeant Dianne Uro'o of the Royal Papua New Guinea Constabulary (RPNGC) in carrying out HIV/AIDS and other community policing awareness in collaboration with NGOs in the Markham area of Morobe Province.

2 The PNG Post-Courier (23 September 2009) reports 22 women participating in training to become community auxiliary police in Buka with a particular emphasis on dealing with problems of sexual abuse and domestic violence experienced by women in rural Bougainville.

3 The PNG Post-Courier (30 January 2009) reports that more than 400 youths from Port Moresby South graduated with certificates of recognition for community policing. The youths had been attached with the police in the National Capital District during the festive period in partnership with the National Capital
} 
model of governance at local levels, there is a growing acknowledgement of the need for limited and strategic interventions by external actors (whether state, donors, private or non-government organisations) that do not undermine the spontaneity, autonomy and self-direction of local initiatives. The state should ideally provide an enduring structuring element with a focus on enabling and helping to sustain state/community partnerships aimed at promoting community safety and wellbeing.

Hybrid justice initiatives are, of course, nothing new in PNG. The Village Courts established shortly after independence represent the most prominent institutional example and simultaneously source their authority and legitimacy in both state law and local norms. Village Courts were established as a pragmatic response to the need for a bridging mechanism between the normative orders and modus operandi of community and state. They also serve the practical purpose of diverting cases and individuals away from the congested formal court system. The creeping formalism in these courts highlighted by some critics (Paliwala 1982) reflects their adaptation to local expectations and the fact that they are resorted to when other informal methods of conflict resolution are considered inappropriate to the case in question. Given their serious neglect by successive governments, including failure to provide financial support in the decade following the enactment of the Organic Law on Provincial and Local Level Government in 1995, these courts generally do a good job and have proven to be remarkably resilient across a range of diverse local contexts (Goddard 2009). Moreover, despite longstanding criticisms of Village Courts on the grounds of their lapse from international and PNG constitutional standards of human rights and gender equity, recent moves to increase the number of women officials, including magistrates, and enhance conformity to these standards appear to be meeting with some success. ${ }^{4}$

Community engagement of the kind envisaged in the national law and justice policy is clearly not without risks and tensions will continue between local sociality, the state, and values promoted by global human rights discourse. Ignoring these localised forms of 'doing justice' in the hope that they will be progressively supplanted by a uniform system of state administered justice is, however, totally unrealistic, not least given the limited fiscal capacity of the PNG state. Ultimately the most important things are to work out what kind of 'hand' the state extends to community peacemaking/building, reliable systems

District's Yumi Lukautim Moresbi (Lets Keep Port Moresby Safe) program.

4 Speaking at the launching of the second phase of the PNG-Australia Law and Justice Partnership (PALJP), the Australian High Commissioner noted successful efforts to revitalise village courts and increase the number of women magistrates (PNG Post-Courier 9 June 2009). 
of incentives to foster conformity to acceptable standards, and some latitude with respect to the 'rights' outcomes as purism in this respect will invariably cast local initiatives in the worst of lights (cf. Reid this volume, chapter 13).

\title{
A Grass Roots Governance Model: South African Peace Committees
}

\author{
John Cartwright, Madeleine Jenneker and Clifford Shearing
}

\section{Introduction}

In the first chapters to this volume Luker and Dinnen draw attention to a model that has been developed in South Africa, and tested in Argentina, and that has established a simple and routinised set of institutional arrangements for bringing people together in deliberative forums to create 'a better tomorrow' in response both to specific disputes and more general issues of community development. They also mention the work of Aral, Burris and Shearing (2002) who have argued for the applicability of this model in responding to sexually transmitted infections. The editors have asked us to set out briefly the nature of the model's arrangements and the way in which they are being used in South Africa.

This model was developed by researchers at the Community Peace Programme (a unit of the School of Government at the University of the Western Cape) using a methodology that involved them working closely with members of a pilot community in a trial and error 'experimental' fashion to shape a workable set of procedures that operate within a regulatory framework that identifies and promotes liberal-democratic values embodied by the South African state.

\section{The Community Peace Programme}

The Community Peace Programme coordinates, facilitates and supports people engaged in re-imagining and transforming the way in which governance generally - and safety and security in particular - is accomplished. In doing so, it develops, reflects upon, and makes available, innovations in governance.

Its aim is to facilitate the validation, and effective application, of local knowledge and capacity as a massive but under-valued resource, making it possible for communities of 'ordinary' citizens to enter into effective partnerships of mutual respect with state agencies and specialist professionals. 
In doing so it seeks to overcome the marginalisation of local knowledge that often occurs in governance programmes in poor and disadvantaged communities in ways that ensure that it is recognised and related to other forms of knowledge used to build community harmony and safety.

\section{The Challenge}

- Whose knowledge and experience is valued?

- By what means, and through which agencies or institutions, is security with justice produced in any given community?

- How can the knowledge and experience of civil society organisations and actors be effectively and sustainably mobilised to promote legitimate common interest?

- How can broad-based concepts of justice and human rights be integrated into social projects?

- What, in these circumstances, are the responsibilities of the state? What forms of cooperation or partnership between the state and civil society give most effective expression and implementation to their varied strengths and capacities?

\section{The Post-Apartheid South African Context}

Questions of this kind became especially prominent in public life in South Africa in the early 1990s following the collapse of the apartheid regime. Anything seemed possible, and there was - and to some extent continues to be - an exceptional opportunity to think freshly about the kind of society South Africans wished to live in. 'Reconstruction and Development' was a key slogan of the new government for the first few years, and-encouraged by the enlightened guidelines laid down in the new national Constitution - a great deal of energy and creativity went into developing policies and strategies aimed at social transformation.

For example, in the area of safety and security - crucial issues in a period of radical social change - the concept of 'policing' was revisited. There was general agreement that policing ought not to be viewed as the exclusive responsibility of the police, or, indeed, of the state. A broader conception was preferred that viewed security as the collective responsibility of networks of state agencies and commercial and non-commercial 'partners'. The possibility was thus opened up of taking more seriously the capacity of communities to contribute to their own safety and security, and, of course, other aspects of their wellbeing (Dixon 2004). 


\section{The Beginnings}

In late 1997, with the active encouragement of the then Minister of Justice, the Community Peace Programme launched a deliberative model-building experiment in Zwelethemba, a suburb of the rural town of Worcester in the Western Cape. The Xhosa name for the suburb, Zwelethemba, means 'place of hope'. Specifically, the focus was to be on questions of safety and security in the local context, and the aim was to build a sustainable model of governance, based on the mobilisation of local knowledge and capacity around issues of dispute resolution and community-building.

This work was concerned with developing structures and ways of doing things that could be sustained over time and that enable poor and disadvantaged people to:

- Play a significant role in directing what happens in their communities;

- Rely on their own knowledge and capacity in their planning and in implementing these plans;

- Coordinate this knowledge and capacity with state agencies, and

- Access money to support their planning and the implementation of these plans.

\section{Governance and Security}

The Peace Committee model is designed to enable people to manage their own lives more effectively. Although its aims are general (that is, the whole of people's lives), it approaches general things in very specific and concrete ways by giving priority to disputes. The model sees most disputes as problems that are usually small in themselves but which, if not dealt with, can quickly escalate to disastrous proportions. It also regards disputes as related to more generic issues.

There are two main processes in this model — 'PeaceMaking' and 'PeaceBuilding'.

\section{PeaceMaking}

Peace Committees operate according to a Code of Good Practice (see below). When a dispute is brought to a Peace Committee, an agreed set of procedures is followed. A 'PeaceMaking Gathering' is arranged, usually within days. Its purpose is to bring together the disputants and any other people who may be in a position to help understand and resolve the dispute. In this process, the role of the Peace Committee members is to facilitate what happens at the Gathering. They do not see themselves as problem solvers but as persons who 
facilitate problem solving by the parties to the dispute. The Gathering is guided through several stages, with all those present being encouraged to take part. In the first place, statements and discussion are heard on what happened and its consequences. This is followed by an attempt to identify the root cause(s) of the problem. Finally there is discussion aimed at producing an appropriate action plan, agreed to by all and designed to ensure that the problem does not recur. The focus of the Gathering, therefore, starts with the past problem and moves progressively towards ensuring a better and more secure future. Unlike formal criminal justice procedures which are concerned with past events, it is essentially a future-focused process. ${ }^{5}$

\section{Here is a more detailed account of the PeaceMaking process:}

- People in communities establish groups of 5-20 people, who call themselves a Peace Committee. The purpose is to create a sustainable institutional structure that people in the community, government agencies and others can relate to.

- The Peace Committee announces itself within the community as a group who will facilitate the resolution of disputes. When this happens the Peace Committee tells the community about their values. They do this by stating and making available a Code of Good Practice that says 'Here are our values; here is what we are committed to'. One of the most fundamental of these is that 'we don't use force to solve problems'. The purpose of the Code is to ensure that people know the key values of the Peace Committee and, thereby, what to expect if they opt to take their dispute to a Committee.

- Why would people choose to bring a dispute to the Committee? People usually do this because they do not want the blaming and punitive approach that underpins the operations of the criminal justice system, but also because they do not wish to take the vigilante route which is relatively common in poor communities in the larger South African cities.

- Once a dispute has been brought to the Peace Committee, it assigns two or more members to facilitate a dispute resolution.

- Once the Peace Committee understand what has been going on, they organise a PeaceMaking Gathering that includes the disputants and other people who they think will be able to contribute to solving the problem. Selecting members of the Gathering is very important as these people bring with them knowledge and resources that can help solve problems. Having the right people from the community involved ensures that solutions will be

5 For a discussion of the implications of this way of resolving problems for an experience of justice see Shearing and Johnston, 2005. 
community-based and that decisions taken will respect peoples' values and the way they live.

- Gatherings usually take place in the house of a Peace Committee member, in a room at a community centre, or in a Community Peace Centre (see below under Project iThemba). Wherever it is held, the atmosphere is informal and non-threatening.

- After reading the Code of Good Practice, the first thing that facilitators do is to hear from the disputants separately as to what the dispute is all about. The reason for this separation is to ensure that a single account by one or more of the disputants does not frame the events. The purpose, at this stage, is not to decide who is right and who is wrong but to try and identify the causes of the problem and to find out who is likely to be able to help in solving it. No one is labelled as a victim or an offender. Rather they are seen as people who have a dispute in need of resolution.

- At a Gathering (whether for PeaceMaking or for PeaceBuilding) the focus is always on the future. The question asked is 'what can be done to reduce the likelihood of this and similar problems happening again?' As already noted, this does not mean that participants do not talk about the past. The past will be discussed in order to discover what can be done to ensure a better tomorrow.

- Once a plan of action has been finalised, it is recorded in writing and everyone signs to show his or her commitment to it. If specific actions are required, the plan will list them and identify who is responsible for doing these things. The purpose here is to ensure that everyone knows exactly what has been decided so that they can make sure that it is subsequently acted upon. One or more people at the Gathering are assigned the role of following up to see that the plan of action is followed.

- At the end of the Gathering disputants might apologise to each other. They may also choose to shake hands or hug each other. But this is not seen as essential. It is useful insofar as it contributes to people being able to move forward. However, the disputants may also decide that this is neither necessary nor helpful. When this happens there may be no apology.

- The close of a Gathering will invariably be accompanied by an act that symbolises the commitment of those present to what has been decided. This might be a dance, a song, a prayer, holding hands, or a combination of such things.

Peace Committee members who participate in a PeaceMaking Gathering prepare a report on what has happened. This goes to a central office where statistics are prepared, and feedback is then given to each Peace Committee on a monthly basis. 


\section{Code of Good Practice}

Members of this Peace Committee use these guidelines in the course of their work as peacemakers:

- We help to create a safe and secure environment in our community.

- We respect the South African Constitution.

- We work within the law.

- We do not use force or violence.

- We do not take sides in disputes.

- We work in the community as a co-operative team, not as individuals.

- We follow procedures which are open for the community to see.

- We do not gossip about our work or about other people.

- We are committed in what we do.

- Our aim is to heal, not to hurt.

Disputes and other problems brought to PeaceMaking Gatherings for facilitation include such matters as unpaid loans and child maintenance, insults and fighting, theft and domestic violence. The coming together of appropriate local people in a facilitative environment is the key to the resolution of these dispute and the preparation of an agreement based on practical and effective plans of future-oriented action.

\section{Payments}

Before proceeding to the PeaceBuilding part of the model, we need to consider the matter of payments. For every Gathering that is completed according to the rules agreed upon, a payment is made to the Peace Committee. This is in recognition of the value of the work that the Committee does and responds to the common complaint that while professionals are always paid, poor people are usually asked to volunteer.

A proportion of this payment - currently two-thirds - goes to the individual Peace Committee members who facilitated the PeaceMaking Gathering, while one third goes into a PeaceBuilding Fund. This Fund is used to finance projects or individuals who have developed responsible entrepreneurial schemes for addressing some of the long-term problems in the community. This ensures that communities have money of their own. It is not a grant or a handout. Rather, it is money that they have 'earned' and is to be spent on activities aimed at building a better future for the community. 


\section{PeaceBuilding}

PeaceBuilding works in the same way as Peacemaking except that the Peace Committee is here addressing broader generic problems rather than dealing with individual disputes. When there is an emerging pattern of local disputes or where the findings of regular base-line surveys indicate the existence of underlying problems confronting the community, the Peace Committee may decide to arrange a Solutions Gathering. Such a Gathering - often consisting of a series of meetings - is held to work out a long-term solution to these deeper problems and to establish who is to carry out the necessary work. The idea is to pay for this service out of the money accumulated in the PeaceBuilding Fund and to ensure that as much of this money stays in the community as possible. In addition, the Peace Committee might negotiate with others to increase the funds available for a project-for example, through a contract with a local municipality.

The PeaceBuilding process develops the model from a conflict management orientation to a broader governance focus. Individual disputes are seen as starting-points, issues that bring people together and mobilise their local knowledge and experience. Disputes in this sense constitute a 'window' through which one can proceed to identify and then address more general governance issues.

Many of the projects that emerge out of Solutions Gatherings are ones that, in one way or another, involve public health, for example, feeding schemes, touring drama groups to educate people about health issues, food gardens, first aid training, clearing public recreation areas of debris such as broken glass and so on.

\section{Outcomes}

By February 2005, there were 20 Peace Committees in South Africa, and together they had facilitated the resolution of over 11,000 Peace Gatherings. These Gatherings generated about R2,500,000 in revenues for Peace Committees. All of these revenues have been spent in these communities.

The authors of this chapter have analysed the reports of some 7000 Gatherings, which took place over the four years prior to 2005. Approximately 60,000 people had participated directly in solving problems in their communities through the 'window' of Gatherings. That is, 60,000 people have had the experience of shifting their stance from one of dependency on external agencies to one of assuming responsibility for resolving their own problems and, in the process, 
have moved from an orientation of blame to one that is focused on creating a new future. On average, 5.6 Peace Committee members were involved in each gathering.

In the Gatherings analysed, 59 percent of the participants were women, and 17 percent were youth. Of the Peace Committee members who facilitated Gatherings, 62 percent were women. The most frequent issues (36 percent) dealt with by Gatherings were to do with money (e.g. money-lending disputes, nonpayment of loans or for goods and misappropriation of funds). Insults, threats and gossiping made up 17 percent of the total number, while property offences made up 20 percent. In 96 percent of the Gatherings, the participants developed a course of action and people committed themselves to implementing it. In a little under three-quarters of the gatherings some gesture marking the end of the conflict took place. At times this involved everyone present making a commitment to peace. At other times only the disputants were involved.

\section{Relations with State Agencies}

The continuing evolution of the Peace Committee model takes place against the background of a very important question. That is, what kind of partnership can be built between the state and civil society, in which the resources, knowledge, capacities and responsibilities of each party can be given practical and effective expression?

From the beginning of the pilot project in Zwelethemba in 1998, a good working relationship was established with the South African Police Service (SAPS) and the Department of Justice at both national and the provincial levels. Similarly, informal relationships of mutual referral have since been established with the Station Commissioners and magistrates in areas in which the Peace Committees operate. However, an important further step in improving cooperation has been taken with the establishment of Project iThemba, as described in the following section.

\section{Project iThemba}

In April 2002, the Community Peace Programme was approached by the SAPS Area Commissioner in the Boland (a region of the Western Cape) to consider the possibility of a cooperative venture in the township of Nkqubela, Robertson. The satellite police station in Nkqubela had been closed for some time owing to lack of resources and the Commissioner was under pressure from the local community to restore services. 
After extensive negotiation, the principles and outline of a cooperative agreement became clear. In effect, the new Nkqubela Peace Committee would provide a conflict-resolution and community-building service, while the police would provide a contact point for reports and enquiries, an emergency response service, and a conduit for bringing appropriate cases to the courts. The former police station would be refurbished and extended and would reopen as a Community Peace Centre. An important feature of the refurbishment was the re-branding of the building by using both the emblems and colours of the SAPS and the Peace Committees.

After appropriate community consultation, the Nkqubela Peace Committee began work in late June 2002. Twenty-two police reservists were trained with Community Peace Programme and Peace Committee input. The Nkqubela Community Peace Centre was formally opened on 19 October 2002, in the presence of representatives of the Finnish Embassy (who provided some financial assistance to the project), the SAPS Western Cape management, the Mayors of the Boland District Council and the Breede River-Winelands Municipality, and the Western Cape Committee for Community Safety.

Project iThemba ("iThemba" means "hope") in Nkqubela was seen explicitly as a pilot project, with the intention of extending the model in due course throughout the Boland SAPS Region. Subsequently, the Zwelethemba Community Peace Centre was launched on 28 February 2004, and the Mbekweni Community Peace Centre was formally opened on 1 April 2004.

\section{This Partnership Works as Follows:}

- The SAPS carry out regular police work - that is, law enforcement, emergency response and detective services;

- The Peace Committees facilitate the resolution of disputes, conflicts and problems that do not require police action;

- Community members may take their problems directly to the Peace Committee for facilitation;

- Alternatively, the SAPS shift officers in the Community Peace Centre may offer disputants the option of taking the matter to the Peace Committee rather than opening a docket or following some other formal bureaucratic route;

- The Peace Committee may also refer matters to the SAPS where appropriate;

- The SAPS notes referrals to the Peace Committee, while Peace Committees complete a detailed report-form for all facilitations that they carry out.

In addition to providing an effective service to the residents of these communities, this Project is intended to demonstrate the feasibility and sustainability of an active partnership between state agencies (the police and local government) and a 
civil society organisation, as well as between professional or 'expert' knowledge and local community knowledge. This is a partnership whose practices are premised on respect for each other's culture, capacity and experience. In particular, and in relation to national policy on policing, the Community Peace Centre model gives effective expression and implementation to the principles of Sector Policing which is the process being used by the SAPS to implement the principles of community policing.

\section{Extension of the Model}

Other communities are being encouraged to adopt the model, provided they recognise a copyright (which is provided free of charge) and constitute themselves as an Implementing Agency willing to have their activities certified on a recurring basis through audits to ensure that the integrity of the model is preserved.

\section{Conclusion}

The model outlined here has now been tested well beyond the original pilot site. Moreover, procedures have been developed for ensuring sustainability and the utilisation of local knowledge and capacity. In addition, detailed operational procedures for managing Peace Committees on a wider scale are being constantly refined as the network is extended. As part of this process, it has been agreed that the Community Peace Programme should adopt a regulatory role, in relation both to financial accounting and to the monitoring of the PeaceMaking and PeaceBuilding procedures.

This is being done through a deliberative crucible of practice, which ensures that local people are part of the process by which the applicable principles and procedures are developed. This insistence on the full participation of civil society is matched by an insistence on pursuing mutually respectful partnerships with state agencies.

To conclude, the strength of this model lies in:

- the lawful and effective mobilisation of local knowledge and capacity around local conflicts and generic community problems;

- the development of complementary civil society-state agency relationships in promoting public goods. 
Civic Insecurity

\title{
Building Community and Peace in Saraga Settlement, Port Moresby
}

\author{
Isaac Wai and Paul Maia ${ }^{6}$
}

\section{Background}

Saraga was once a traditional Motu Koitabuan village on land that was later to become part of the modern city of Port Moresby, the capital of Papua New Guinea. It is now a sprawling urban settlement in the area known as Six-Mile, indicating its approximate distance from the commercial centre of the city. As Port Moresby grew, Saraga became home to many migrants from other parts of the country. The first groups of settlers from the mountainous and undeveloped Goilala region to the north of the capital arrived in 1949. Settlers and customary landowners agreed that, in return for rights to use the land, the former would provide the local Motu Koitabuans with security and labour. These first settlers arrived at a time when the colonial administration in Port Moresby was recruiting casual labourers for a variety of tasks. Labourers were recruited from different districts in PNG and usually arrived in Port Moresby unaccompanied. As the years went by, relatives of these labourers began to join their wantoks in urban settlements like Saraga. This movement of people from rural areas, along with new births, contributed to the growth of the urban population and the extension of tambu (in-law) relationships between different groups of people. Saraga developed in this way and the current population includes third and fourth generation residents who now identify themselves as Saraga people. In 1999, the Saraga Peace, Good Order and Community Development Association undertook a community survey that indicated that the settlement had a population of approximately 17,000 people representing around 34 ethnic groups.

From the 1970s, Saraga acquired an unfortunate reputation among Port Moresby residents as a breeding ground for criminal elements - an urban Wild West populated by gangs and other lawless characters engaged in a range of illicit and violent activities including murder, tribal fights, rape, raskolism, car thefts, break and enters, and armed hold-ups. The general public, and even the police, avoided going near Saraga, particularly at night. Among the urban population, Saraga was a place that primarily inspired fear and insecurity.

\footnotetext{
6 At the time of writing, Isaac Wai was the Deputy Chairman and Paul Maia was the Chairman of the Saraga Peace, Good Order and Community Development Association based at Six-Mile in Port Moresby. This account of peace-making in Saraga is based on an article by Isaac Wai and Paul Maia and is reproduced here in edited form with the permission of the authors and the Development Bulletin.
} 


\section{Association Formation}

On 9 February 1998, a nine year-old girl from Rigo in Central Province was shot dead by young criminals on the Magi Highway in the vicinity of Saraga. Prominent leaders from Central Province, the national government, Motu Koitabu landowners, and many members of the public called for the immediate removal of all settlers from Saraga and their repatriation back to their provinces of origin. This was a difficult and worrying time for many law-abiding residents of the settlement who feared for their future and that of their families.

The broader context to the high levels of crime and violence engaged in by some members of the community was one of chronic unemployment and a large and growing body of alienated youngsters with little to do and limited access to legitimate economic activities (cf. Luker and Monsell-Davis this volume). Following the 1998 murder, an anti-crime campaign was initiated in Saraga by the then Central and National Capital District Police Commander, Jeffrey Vaki. The essence of this police initiative was to persuade criminal and anti-social elements to desist from their predatory and destructive activities and to threaten eviction and repatriation for those who did not. Following the campaign, Paul Maia, a long-term resident of Saraga and co-author of this account, called an urgent meeting of all community leaders with a view to establishing a mechanism that could help develop a vision for the future wellbeing of the community, while becoming an important forum for residents. It was at this meeting that the idea of establishing a system of committees to represent each of the community's ethnic groups and help foster and sustain peace and harmony within the settlement was first conceived. Subsequently each group established its own law and order committee. The response of community leaders at this initial meeting was overwhelmingly favourable and an overarching body - the Saraga Peace, Good Order and Community Development Association - was established with the aim of developing strategies to combat law and order problems occurring, or originating, in the community, while simultaneously building community cohesion and capacity.

The Association's broad aims and objectives were stated as follows:

- Promoting Good Governance-helping to achieve good governance, respect for human rights, and the promotion of conflict prevention. One of the ways in which this was to be achieved was through the establishment of a community coalition comprising community representatives, business houses, and government officials, working together to help restore and maintain law and order.

- Promoting human development - helping people achieve higher levels of education and widening the opportunities for disadvantaged members of the community. 
- Promoting the status of women-contributing to the removal of gender discrimination and encouraging greater participation of women in all aspects of community life. Pursuing this goal would involve liaison, coordination and enhanced networking between all collaborating agencies and organisations to ensure that high levels of violence against women were addressed.

- Prevention of delinquency - diverting community youth into lawful and socially useful activities. This would entail fostering more respectful and socially responsible attitudes on the part of young people - as well as attitudes towards young people - in order to counter criminal and anti-social tendencies. In this regard, PNG's Juvenile Justice Act should be immediately implemented to provide for an effective system of juvenile justice that, in conformity with PNG's international obligations under the UN Convention on the Rights of the Child, is respectful of the rights of juveniles and responsive to their specific needs.

- HIV prevention - promoting the use of Karamap (locally produced) condoms as part of a community-based safe sex and HIV awareness campaign.

- Protection of the environment-contributing to the protection and sustainable management of the local environment. Strategies included treeplanting in the community.

- Conflict mediation-undertaking peace mediation between parties in dispute following restorative justice principles aimed at conflict resolution, reconciliation and community harmony.

- Skills training for engagement in the informal sector - training for sustainable livelihoods in the informal economy and enhancement of formal employment skills.

\section{Activities}

Following its establishment, the Saraga Peace, Good Order and Community Development Association embarked on a series of planning exercises relating to law and order issues, started monitoring community activities and liaising directly with local groups and external agencies and organisations in the promotion of its broader agenda for community regeneration. Among other things, association members approached a number of neighbouring business houses with a view to eliciting support for community sports activities and securing casual or part-time employment for local youth. These efforts met with some success and sports equipment was provided by commercial sponsors, while job opportunities were presented to a number of local youngsters. The Association's activities are described in more detail below. 


\section{Community Sports Sponsorship}

Sports sponsorship secured by the Association helped create new opportunities for community youth to socialise and engage in healthy recreational activities. These sporting activities initially involved 355 participants and approximately 35 supervisors. They also attracted large numbers of spectators and provided additional income-generating opportunities to members of the community who sold home-made produce at the sides of the two sports fields.

Sponsorship was provided by a locally based firm, the Downer Construction Company, with a package of K25,000 distributed at K5000 per year. At a ceremony announcing the sponsorship, the company's general manager, Greg Wright, said that the community's reputation as a home to criminals reflected the limited work opportunities available, serious overcrowding, and the proliferation of raskol gangs. These factors contributed to the urban law and order problems identified by government, police and the private sector. Mr Wright said that his company was proud to sponsor community sports activities in Saraga. The sports program was a way of breaking down barriers between Saraga's different ethnic groups and building community cohesion and harmony.

\section{Law and Order Awareness}

The British High Commission also provided support to the Association to conduct law and order awareness in the community. Leaflets were prepared containing basic legal information and subsequently distributed among the 34 ethnic groups by their respective committees. Issues covered included domestic violence, laws about alcohol, home brewing, marijuana, sexual offences, recent changes to PNG laws, child abuse and children's rights.

\section{Peace Mediation and Restorative Justice}

Peace mediation according to restorative justice principles has deep roots in Melanesian cultures and has been adopted by the Saraga Good Order and Community Development Association as an appropriate technique for mediating conflicts within the community. Mediation training had been provided to some community leaders by the Port Moresby-based NGO - Peace Foundation Melanesia - and was subsequently adapted for use in Saraga. This technique was used to mediate conflicts between different ethnic groups in the settlement arising from six murders that occurred in the period 1997-2004 and continues to be used today. Association members involved in mediating conflicts sought to address the underlying grievances between different groups in the community and reconcile their differences. Emphasis was placed upon the reintegration of offenders after reconciliation with their victims and making suitable reparation. 
Individuals are encouraged to take responsibility for their actions and change their attitudes accordingly. The ultimate aim is to increase respect between different groups and individuals and thereby enhance peace and harmony in the community. Upon completion of a successful conflict mediation process, Peace Declared Memorandum of Understanding forms are drawn up by Association members with specific conditions attached. All parties to the conflict agree to these conditions and sign the forms confirming that peace has been restored. The mediation panel also signs the forms, thereby sealing the peace agreement, and, where possible, a police station commander witnesses the signing. Upon signing the peace agreements, the parties to the conflict become solely responsible for repairing any damage caused in accordance with the conditions specified in the agreement.

This approach has proved to be extremely useful and, as an alternative to going through the formal criminal justice process, provides some relief to the already overburdened police, courts and prisons. The Association has developed a good working relationship with the local commander at the Six-Mile police station. Minor summary offences committed in the settlement and cases involving juveniles are registered in the police occurrence book and are often referred back to the Association for mediation. After the mediation group has dealt with a case, it reports back to the Six-Mile police who then finalise the incident reports at the station. Cases mediated by the group have included stealing, bag-snatching, conflicts relating to alcohol consumption, tribal fighting, gossiping, domestic violence, child abuse, false allegations, adultery, broken marriages, bride-price, attempted rape, land disputes, non-payment of credit and possession of marijuana.

\section{Major Sponsors}

The association has received support and encouragement from a number of government agencies and NGOs, as well as from some business houses. The Community Justice Liaison Unit - a donor-funded initiative with the law and justice sector-aims to foster partnerships between government agencies and civil society groups involved in crime prevention and conflict resolution like the Saraga Association. Recognising the merits of the Association's work, the Unit has contributed K12,874 towards community sporting activities. Small incomegenerating activities - such as the sale of food and drinks - have also benefited from this support to community sporting events. The Community Justice Liaison Unit has also agreed to fund a multi-purpose community hall in Saraga. This will allow all the community groups involved in crime prevention and violence reduction activities to come together under the one roof. Downer Construction and a local security company, Pacific Corporate Security, have provided financial and logistical assistance since the establishment of the Association. The security 
company has also provided employment opportunities to members of the different ethnic groups in Saraga. It has also provided an efficient community communication system linked to its radio network that has been an invaluable resource in enabling the Association's committee network to respond in a timely manner to crime and conflict in the community. While Downer Constructions has subsequently ceased its operations in PNG, its successor company-Omni Limited-has continued to provide the association with logistical support.

\section{Looking Ahead}

Planned activities include:

- Building a multi-purpose community hall;

- Installing electricity and streetlights in selected areas

- Installing and extending water supply in selected area and increasing water pressure;

- Building sewerage blocks to improve hygiene in the community;

- Establishing poverty alleviation schemes such as food gardens; poultry keeping; and flower planting;

- Improving the mobile clinic service;

- Vocational skills training for local youth (boys and girls);

- Environmental work in the community and elsewhere in the city;

- Preparing leaflets and promoting community awareness about sexual violence, alcohol and drugs;

- Increasing participation in sports and developing competitions with other settlements and villages.

The Association remains focused on community-building as the essential foundation for improving safety and harmony in the settlement. Considerable efforts are directed at developing and maintaining partnerships and linkages with relevant government agencies, NGOs, and the private sector, in order to assist the Association's work.

\section{Conclusion}

Association leaders appreciate that addressing law and order problems is not only a task for government and police. It is also an issue that requires active participation by ordinary members of the community, drawing on local knowledge and expertise. Building partnerships for change between community organisations, government agencies and business houses, is an important aspect of building stronger and more stable communities. 
The Association is committed to developing strategies that will include all of the various ethnic groups making up Saraga and develop a strong sense of belonging to the same community. Meeting regularly to discuss issues affecting the community and working together to devise appropriate solutions to identified problems has helped overcome some of the divisions and suspicions that have undermined community cohesion in the past. It is also about empowering the community to take responsibility for the challenges it faces on a daily basis and devising approaches that build on local knowledge and expertise.

\section{References}

Aral, S., S. Burris and C. Shearing. 2002. Health and the Governance of Security: A Tale of Two Systems: Crime Control and Sexually Transmitted Diseases in Russia. Journal of Law, Medicine and Ethics 30: 632-643.

AusAID. 2007. Democratic Governance Program. Information Note - July 2007. Canberra: AusAID

Boege, Volker. 2009. Peacebuilding and State Formation in Post-Conflict Bougainville. Peace Review 21 (1) January-March 2009, 29-37.

Burris, Scott. 2006. From Security to Health. In Democracy, Society and the Governance of Security, ed. Jennifer Wood and Benoît Dupont, 196-216. Cambridge: Cambridge University Press.

Christie, Nils. 1977. Conflicts as property. British Journal of Criminology 17 (1), 1-14.

Clifford, W., L. Morauta and B. Stuart. 1984. Law and Order in Papua New Guinea (Clifford Report). Port Moresby: Institute of National Affairs and Institute of Applied Social and Economic Research.

Dixon, B. 2004. Cosmetic Crime Prevention. In Justice Gained? Crime and Crime Control in South Africa's Transition, ed. B. Dixon and E. van der Spuy, 163192. Cape Town: University of Cape Town Press and Willan Press.

Emmett, Tony and Alex Butchart eds. 2000. Behind the Mask: Getting to Grips with Crime and Violence in South Africa. Cape Town: HSRC Publishers. www. hsrcpress.ac.za

Fraenkel, Jon. 2004. The Manipulation of Custom. From Uprising to Intervention in the Solomon Islands. Wellington, NZ: Victoria University Press. 
Garap, Sarah. 2004. Kup Women for Peace: Women Taking Action to Build Peace and Influence Community Decision-Making. State Society and Governance in Melanesia Discussion Paper 2004/4, 1-16. Canberra: Australian National University.

Goddard, Michael. 2009. Substantial Justice. An Anthropology of Village Courts in Papua New Guinea. New York and Oxford: Berghahn Books.

Goudsmit, Into A. 2008. Nation Building in Papua New Guinea: A Local Alternative. State Society and Governance in Melanesia Discussion Paper 2008/9, 1-15. Canberra: Australian National University.

Government of Papua New Guinea (GoPNG). 2000. The National Law and Justice Policy and Plan of Action: Toward Restorative Justice.

Hegarty D. and Pam Thomas eds. 2005. Effective Development in Papua New Guinea. Development Bulletin No. 67 April 2005. Canberra: Development Studies Network.

Hinton, R., M. Kopi, A. Apa, A. Sil, M. Kini, J. Kai, Y. Guman, and D. Cowley. 2008. The Kup Women for Peace approach to peacekeeping: taking the lead in the Papua New Guinea national elections. Gender \& Development 16 (3): 523-533.

Howley, Pat. 2002. Breaking Spears and Mending Hearts: Peacemakers and Restorative Justice in Bougainville. London and Sydney: Zed Books and Federation Press.

James, Paul, Victoria Stead, Yaso Nadarajah, Karen Haive. 2009. Projecting Community Life, themed issue, Local Global: Identity, Security, Community 5.

Justice Advisory Group (JAG). 2004. Community Justice Situation Audit. Report prepared for JAG by Lawrence Kalinoe.

Paliwala, Abdul 1982. Law and order in the Village: the Village Courts. In Law and Social Change in Papua New Guinea, ed. D. Weisbrot, A. Paliwala and A. Sawyerr, 191-217. Sydney: Butterworths.

Parenti, C. 1999. Lockdown America: Police and Prisons in the Age of Crisis. London and New York: Verso.

Regan, Anthony. 2005. Clever people solving difficult problems: perspectives on weakness of the state and the nation in Papua New Guinea. Development Bulletin 67, April 2005, 6-12.

Shearing, C. and L. Johnston. 2005. Justice in the Risk Society. Australian and New Zealand Journal of Criminology 38 (1) April 2005: 25-38. 
Shearing, C. and Stenning, P. eds. 1987. Private Policing. Newbury Park, CA: Sage Publications.

Singer, P.W. 2003. Corporate Warriors: The Rise of the Privatised Military Industry. Ithaca, NY: Cornell University Press.

SPSN (Strongm Pipol Strongim Nesen). [n.d.] 'Empower People: Strengthen the Nation'. Draft Executive Summary.

Wai, Isaac and Paul Maia. 2005. What We Do in Saraga: Building Community Peace and Harmony, Development Bulletin, No. 67 April 2005, 53-55.

Weber, Max. 1972. Politics as a vocation. In Max Weber, ed. H. H. Girth and C. W. Mills. New York: Oxford University Press. 